TEME, г. XLI, бр. 4, октобар - децембар 2017, стр. 981-998

Оригинални научни рад

DOI: $10.22190 /$ TEME1704981M

Примљено: 12. 1. 2017.

UDK 159.923.5-057.875

Ревидирана верзија: 26. 8. 2017.

Одобрено за штампу: 15. 11. 2017.

\title{
АСЕРТИВНОСТ И ДЕПРЕСИВНА ЛИЧНОСТ СТУДЕНАТА ПЕДАГОШКОГ И МЕДИЦИНСКОГ УСМЕРЕЊА НА ПОЧЕТКУ СТУДИЈА
}

\author{
Радмила Миловановић ${ }^{1}$, Зорица Б. Марковић ${ }^{2}$ \\ ${ }^{1}$ Универзитет у Крагујевцу, Педагошки факултет, Крагујевац, Србија \\ ${ }^{2}$ Универзитет у Нишу, Филозофски факултет, Ниш, Србија \\ *ola717ola@gmail.com
}

\begin{abstract}
Апстракт
Асертивност је онај аспект социјалних компетенција који се повезује са социјалном прилагођеношћу, академским и професионалним успехом, социјалним статусом, али и са проблемима усамљености, анксиозности и депресивности. Будући да је асертивност и одсуство депресивних тенденција важно питање изградње професионалних компетенција педагошких и медицинских радника свих профила, истраживање је имало за циљ да испита асертивност и присуство особина депресивне личности код студената поменутих усмерења на почетку студија. Укупан узорак је чинио 521 студент прве године студија (162 студента Факултета педагошких наука УКГ у Јагодини, 136 студената Учитељског факултета у Ужицу, 98 студента Високе медицинске школе у Ћуприји, 72 студента Факултета медицинских наука у Крагујевцу и 53 студента Медицинског факултета у Београду). Асертивност је мерена Скалом за процену асертивности (А скала), док је депресивност испитивана Скалом за процену депресивне личности (ДЛ скала). Резултати показују да је највећи проценат студената на доњој граници категорије просечне асертивности и умерено изражених особина депресивне личности. Није нађена значајна разлика између студената педагошког усмерења и студената медицинског усмерења у односу на асертивност $(\mathrm{p}=0,498)$ и депресивну личност $(\mathrm{p}=0,159)$. Између резултата студената на скали асертивности и скали депресивне личности нађена је статистички значајна негативна повезаност ниског интензитета $(\mathrm{r}=-0,287, \mathrm{p}=0,000)$. Ниво асертивности, као и проценат студената будућих педагошких и медицинских радника са ниском и изразито ниском асертивношћу, као и израженом депресивношћу - указују на неопходност планске активности у правцу развоја асертивности и примену превентивних програма за заштиту менталног здравља младих у току студија.
\end{abstract}

Кључне речи: социјалне компетенције, асертивност, депресивна личност, професионални развој педагошких и медицинских радника. 


\title{
ASSERTIVENESS AND DEPRESSIVE PERSONALITY OF STUDENTS OF PEDAGOGICAL AND MEDICAL FACULTIES
}

\begin{abstract}
Assertiveness is the aspect of social competencies which is related to social adaptation, academic and professional achievement and social status but also to the problems of loneliness, anxiety and depressiveness. Since assertiveness and absence of depressive tendencies are important issues in professional competencies of teachers, pre-school teachers, medical doctors and medical technicians, this research was aimed at examining assertiveness and the presence of depressive personality traits in the students of the mentioned orientations. The total sample consisted of 521 subjects (162 students of the Faculty of Education of the UKG, 163 students Faculty of Teacher Education in Užice, 98 students of the Medical College in Ćuprija, 72 students of the Faculty of Medicine science in Kragujevac and 53 students Faculty of Medicine in Belgrade). Assertiveness was measured using the Scale for the assessment of assertiveness (A Scale) by Tovilović and associates, while depressiveness was examined by the Scale for the assessment of depressive personality (DP Scale) by Novović and associates. The results show that the highest percentage of students belongs to the category of average assertiveness and moderate depressiveness. No significant difference was found between the students of medical orientation and students of pedagogical orientation in relation to assertiveness $(\mathrm{p}=.498)$ and depressiveness $(\mathrm{p}=.159)$. A statistically significant low intensity negative correlation $(r=-.287, \mathrm{p}=.000)$ was found between the achievements of students on the assertiveness scale and the depressive personality scale. Despite the fact that the obtained results are encouraging, the percentage of students, prospective teachers and pre-school teachers as well as medical workers, with low and extremely low assertiveness as well as with prominent depressiveness, indicates the necessity for a planned activity towards the development of assertiveness during university studies and the implementation of prevention programs for the protection of mental health of young people during university studies.
\end{abstract}

Key words: $\quad$ social competencies, assertiveness, depressiveness, professional development of pedagogical and medical workers.

УВОД

Асертивност као аспект социјалних компетенција

Асертивност је мултидимензионални конструкт условљен личним и ситуационим карактеристикама, културним нормама и социјалним вредностима (Terluter et al., 2010). Као релативно нов појам, чије корене можемо тражити у оквиру његове клиничке примене, асертивност се у литератури посматра као социјална вештина (Pfeiffer, 2010), основно људско право (Cowley, 2006), црта личности (Den Hartog, 2004) или тенденција у понашању која се дугорочно развија кроз читаво детињство, кроз учење по моделу и класично условљавање (Zdravković, 2004). Асертивни тренинг, један од најстаријих модела бихевиоралне терапије, представља значајно подручје 
терапијског рада многих терапеута који настоје да помогну људима са недостатком социјалних вештина да превазиђу незадовољавајуће, проблематичне и емоционално болне социјалне интеракције и међуљудске односе (Wolpe, 1990).

У контексту социјалних компетенција, конструкт асертивности посматра се као манифестација социјалне и емоционалне интелигенције или као социјална вештина која доприноси адекватном прилагођавању особе у социјалним интеракцијама, одржавању социјално пожељних односа и емоционалном благостању учесника у социјалној интеракцији (Sarkova et al., 2013). Са̂м термин потиче од енглеског to assert (енгл. глагол са значењем „изјавити, тврдити, бранити”) и assertive (енгл. придев са значењем „упоран, самосвестан, самопоуздан") и представља својеврсну способност самоизражавања (Vagos \& Pereira, 2010). Најчешће се описује у контексту два супротна облика социјалног понашања, субмисивног и агресивног (Van Dyk \& Evans, 2008). Агресивност у социјалном контексту представља самоизражавање које угрожава права других (Cambon, 2010) и има за последицу демонстрацију личне моћи, деструктивне интеракције, емоционалне повреде других, али и одбрамбене и контраагресивне реакције (Thompson \& Berenbaum, 2011). Субмисивност, насупрот томе, подразумева несигурност у социјалним интеракцијама, немогућност изражавања својих мисли и уверења, повлачење и избегавање сукоба на сопствену штету. Особа која реагује субмисивно угрожава своја права, не поштује своје потребе, не поставља границе у односима са људима, има за циљ да задовољи другог (Makai, 2013). Последице субмисивног понашања у социјалним интеракцијама су многобројне. Особа склона овом понашању акумулира дисфункционалне или болне емоције (повређеност, бес, узнемиреност) и постепено губи самопоштовање, лични интегритет и социјални простор за лични раст и развој. Дуготрајна пасивност може бити узрок и физичким тегобама, као што су тензионе главобоље, повишен крвни притисак и друго (Pinquart \& Schiller, 2003). Стална и непрестана потреба пасивне особе да је други људи прихвате, најчешће има супротне ефекте, јер је друге особе мање поштују и занемарују њене потребе, што често има за последицу анксиозност и депресивност (Tavakoli et al., 2009).

Асертивност, као средњи пут, дефинише се као вештина изражавања мисли, осећања и уверења на директан, поштен (искрен) и адекватан начин, уз уважавање права других људи, која укључује специфичне категорије социјалних реакција као што су способност да се каже „не”, способност да се постављају захтеви и траже услуге, започне и заврши конверзација (Lange \& Jakubowski, 1976). Асертивна порука у интеракцији је облик самоизражавања без доминирања, понижавања или било каквог другог угрожавања или повређивања 
осећања или права другог човека. Асертивни људи поштују сами себе као што поштују и друге, умеју да контролишу своје емоције, не траже нити избегавају конфликте и добро се сналазе у конфликтима, не устручавају се да изнесу своје мишљење и неслагање, отворени су за нова решења, имају висок степен одговорности (Pfeiffer, 2010).

Досадашња истраживања указују на постојање високе повезаности између асертивности и самопоштовања (Mirjanić \& Milas, 2009). Самопоштовање се у литератури посматра као одраз врсте и квалитета односа које човек има са другима (Бурушић, 2007). У контексту социјалних компетенција, високо самопоштовање смањује могућности за неуспех у социјалним односима и неприлагођено понашање и повећава могућност пожељних, адаптивних и корисних облика понашања. У контексту менталног здравља, високо самопоштовање је у негативној корелацији са депресивним тенденцијама (Klein et al., 2008).

Истраживања налазе и високу негативну повезаност асертивности и социјалне анксиозности (Hollander \& Simeon, 2006) и указују на то да недостатак асертивности има своју афективну компоненту и да ниска асертивност заузима положај између анксиозности и депресивности (Linet et al., 2008). Подсетимо, асертивност је најпре и проучавана у домену анксиозних и депресивних поремећаја (Olsen et al., 2003). Проучавање неасертивности и последица неасертивног понашања резултирало је описом неасертивних личности као повучених и бојажљивих, као особа које су неспособне да бране своја права, што за последицу има осећање некомпетентности и слабљење самопоуздања. Као узроке неасертивног понашања аутори углавном наводе слабо развијене социјалне компетенције (Gladestone \& Parker, 2005), али и систем особина личности који се у новије време препознаје као посебна нозолошка категорија под називом депресивна личност (Grkinić, 2008).

\section{Конщепт депресивне личности}

Депресивна личност постала је предмет интересовања психологије и психијатрије тек однедавно у контексту склоности ка неасертивном и субмисивном понашању у социјалном контексту. Депресивна личност је у прошлости проучавана под различитим називима. Још је Крепелин 1921. године, проучавајући етиологију манично-депресивне болести, описао овај тип личности назвавши га депресивни темперамент (Maremmani et al., 2005). Особе са депресивним темпераментом Крепелин описује као преозбиљне и изразито ниског самопоуздања. Депресивну личност описује и Шнајдер (Schneider, 1959) као мирну, пасивну, озбиљну, савесну, несамопоуздану и неасертивну особу, скоро идентично као и аутори који се овим проблемом баве последњих деценија (Klein et al., 2008). Поме- 
нути аутори депресивну личност посматрају као екстрем на континууму нормалних варијација личности. Психоаналитичари су, са своје стране, описали особе са депресивном личношћу као особе са ниским самопоштовањем, претерано зависне од подршке и прихватања других, са тешкоћама у експресији агресивних тенденција (Dozois \& Beck, 2008). У најновијој класификацији поремећаја, ДСМ-5 депресивна личност карактерише се смањеним самопоштовањем, високом самокритичношћу и склоношћу ка самоомаловажавању, између осталог (American Psychiatric Association, 2013). У актуелној класификацији менталних поремећаја Светске здравствене организације, депресивна личност се укључује у класу дистимије, блажег и хроничног депресивног стања (World Health Organizacion, 2011). Депресивна личност, важно је нагласити, данас се посматра као екстрем на континууму нормалног функционисања, али и означава као фактор рањивости за настанак клиничких облика депресије.

\section{Асертивност и депресивна личност у контексту професионалних компетенција педагошких и медиџинских радника}

Сматрамо да су асертивност и одсуство депресивних тенденција важни квалитети личности у оквиру развоја професионалних компетенција васпитача, учитеља и медицинских радника, с обзиром на то да омогућују успостављање међуљудског односа заснованог на јасно постављеним границама, отвореној комуникацији, самопоуздању, упорности и доследности, које су неопходне у васпитно-образовном раду (Djigić \& Stojiljković, 2011) и интеракцији медицинских радника са пацијентима (McCabe \& Timmins, 2005). Професионални развој васпитача, учитеља и медицинских радника је континуиран процес, те је јасно да се о професионалним компетенцијама не може говорити независно од образовања и програма њиховог професионалног развоја (Locke \& Sadler, 2007). Програми образовања будућих учитеља, васпитача и медицинских радника требало би да буду конципирани тако да обезбеде развој дефинисаних компетенција. Истраживања показују да је код нас образовање наставника предметно усмерено и да у њему доминира стицање теоријских знања, а да је запостављено развијање методичких и социјалних компетенција (Vilotijević \& Vilotijević, 2014). У контексту образовања медицинских радника, нарочито лекара, социјалне и комуникационе компетенције скоро су потпуно занемарене, упркос чињеници да су интеракције у односу медицински радници - пацијенти све чешће насилне и озбиљно деструктивне. У светлу наведеног, провера асертивности и депресивних тенденција личности будућих педагошких и медицинских радника на почетку студија чини нам се као релевантан подухват, тим пре, што нам није познато да се неко овим питањем бавио раније. Сматрамо да оваква и слична истраживања могу указати 
на правац којим би требало да иде мењање курикулума да би се унапредили и подржали потенцијали будућих педагошких и медицинских радника, али и планирала превенција развоја депресивних поремећаја у студентској популацији.

\section{МЕТОДОЛОГИЈА}

\section{Проблем и изиљ истражсвања}

Полазећи од значаја асертивности и одсуства депресивних тенденција у контексту изградње професионалних компетенција студената педагошких и медицинских усмерења, истраживање је имало за циљ да утврди ниво асертивности и депресивних особина личности студената ових усмерења на почетку студија. Конкретније, истраживање је имало за циљ да испита степен асертивности и степен изражености особина депресивне личности код студената поменутих усмерења, упореди их са нормама добијеним при конструкцији примењених инструмената, провери да ли постоје значајне разлике у односу на студијско усмерење и пол студената и утврди значајност евентуалне повезаности асертивности и особина депресивне личности у испитиваном узорку.

\section{Узорак}

Укупан узорак чинио је 521 студент прве године студија, просечне старости 19,8 година (298 студената педагошких усмерења и 223 студента медицинских усмерења). Структура узорка према студијском усмерењу и факултетима на којима испитивани студенти студирају дата је у Табели 1.

Табела 1. Структура узорка према студијском усмерењу и факултету

\begin{tabular}{lccc}
\hline & $\begin{array}{c}\text { Педагошко } \\
\text { усмерење }\end{array}$ & $\begin{array}{c}\text { Медицинско } \\
\text { усмерење }\end{array}$ & $\sum$ \\
\hline Факултет педагошких наука УКГ Јагодина & 162 & - & 162 \\
Учитељски факултет Ужице & 136 & - & 136 \\
Висока медицинска школа Ћуприја & - & 98 & 98 \\
Факултет медицинских наука Крагујевац & - & 72 & 72 \\
Медицински факултет Београд & - & 53 & 53 \\
\hline$\sum$ & 298 & 223 & 521 \\
\hline
\end{tabular}

Студенткиње су бројније од студената и учествују у укупном узорку са 77,27\% (402 студенткиње и 119 студента). Студенткиње су такође бројније и у подузорцима (педагошко усмерење $87,41 \%$, медицинско усмерење $67,14 \%$ ). Структура узорка у овом истраживању у великој мери одражава реалну полну структуру студената на овим студијским усмерењима у нашој земљи (Mitrović \& Mišković, 2013). 


\section{Инструменти}

За процену асертивности коришћена је Скала за процену асертивности (А скала) (Товиловић и сар., 2009), која је сачињена од ставки које описују реакције и понашања типична за (не)испољавање асертивности. Испитивана особа је инструисана да помоћу петостепене скале Ликертовог типа одговори у складу са својим реакцијама у социјалним ситуацијама које изискују асертивност, у распону од сталне одсутности тих реакција или понашања (никад) до њихове сталне присутности (увек). Од укупно 27 ставки А скале, 13 су ставке позитивног усмерења (у смеру асертивности), док 14 ставки има негативно усмерење. Поузданост А скале је висока (Cronbach's Alpha $=0,960)$. Репрезентативност скале изражена нормализованим КМО износи 0,926, што сврстава скалу у ред скала високе репрезентативности. Испитивања ваљаности скале говоре у прилог добре конкурентне и конструкт ваљаности А скале. Норме за А скалу установљене су на узорку из опште популације старости између 19 и 29 година (нису установљене значајне разлике у односу на старост испитиваних субјеката). Категорије асертивности за општу популацију на које упућују вредности добијених резултата на А скали су: Изразито ниско изражена асертивност (резултат од 27 до 71), Ниско изражена асертивност (резултат 72 до 86), Просечно изражена асертивност (резултат 87 до 103), Високо изражена асертивност (резултат 104 до 119), Високо изражена асертивност (резултат 120 до 135) (Биро и сар., 2009).

За процену депресивности коришћена је Скала за процену депресивне личности (ДЛ скала) (Нововић и сар., 2009). Скала садржи 26 ставки, на које се одговара на основу петостепене Ликертове скале проценом степена слагања са тврдњама. Све ставке су у правцу депресивне личности. Резултат се добија збрајањем заокружених вредности. Поузданост ДЛ скале мерена $\alpha$ коефицијентом је висока (студентски и општи узорак $=0,90$ ). Репрезентативност ставки изражена КМО коефицијентом креће се од 0,88 у студентској популацији до 0,93 у општој популацији. Норме за ДЛ скалу установљене су на узорку студената старости између 18 година и 23 године (нису установљене значајне разлике у односу на старост испитиваних студената). Категорије за општу популацију на које упућују вредности добијених резултата на ДЛ скали су: Одсутне особине депресивне личности (резултат 39 и мање), Умерено изражене особине депресивне личности (резултат 40 до 55), Наглашене особине депресивне личности (резултат 56 до 64), Веома наглашене особине депресивне личности (резултат 65 и више) (Биро и сар., 2009). 


\section{Поступак}

Подаци о асертивности и депресивној личности студената прикупљани су током 2012, 2013, 2014. и 2015. године, у више наврата.

\section{Прочедуре анализе}

Обрада података укључила је методе дескриптивне статистике (учесталост, средња вредност, стандардна девијација), као и методе аналитичке статистике за процену значајности разлика и испитивање корелације. За испитивање значајности разлика коришћен је $t$-тест за независне узорке и $\chi^{2}$ тест. За испитивање повезаности између резултата на скали асертивности и резултата на скали депресивне личности коришћен је Спирманов коефииијент корелаиије. У процесу избора аналитичког модела коришћен је Колмогоров-Смирновљев тест (Kolmogorov-Smirnov test) за тестирање хипотезе о нормалној расподели података.

\section{РЕЗУЛТАТИ}

\section{Асертивност студената}

Да би се испитао степен асертивности студената у укупном узорку и на подузорцима педагошког и медицинског усмерења, најпре је асертивност, изражена кроз добијене резултате, упоређена са нормама које су установљене при конструкцији скале (Табела 2).

Табела 2. Дескриптивни показатељи степена асертивности у укупном узорку, по усмерењима и у нормативном узорку

\begin{tabular}{lccccc}
\hline & $\mathrm{N}$ & $\mathrm{M}$ & $\mathrm{SD}$ & Мин. & Макс. \\
\hline Педагошко усмерење & 298 & 87,27 & 11,91 & 59 & 101 \\
Медицинско усмерење & 223 & 88,03 & 12,14 & 57 & 101 \\
Укупан узорак & 521 & 87,65 & 12,02 & 58 & 101 \\
Нормативни узорак & 727 & 95,25 & 15,34 & 45 & 133 \\
\hline
\end{tabular}

Средње вредности укупног узорка и подузорака припадају категорији просечне асертивности (резултат 87 до 103). Ипак, добијене просечне вредности у укупном узорку значајно су мање $(\mathrm{t}=-4,782 ; \mathrm{p}$ $=0,000)$ у односу на нормативни узорак примењене скале асертивности (Biro i sar., 2009). Добијене просечне вредности у обе испитиване групе такође су значајно мање од просечних вредности нормативног узорка $\left(\mathrm{t}_{\mathrm{n}}=-4,071 ; \mathrm{p}=0.000 ; \mathrm{t}_{\mathrm{M}}=-4,091 ; \mathrm{p}=0,000\right)$.

Даље анализе показале су да разлика између средњих вредности резултата на скали асертивности између студената педагошког и медицинског усмерења није статистички значајна $(\mathrm{t}=1,287 ; \mathrm{p}=0,498)$. 
Такође, није нађена значајна разлика у просечном резултату између полова $\left(\mathrm{AS}_{\text {ж }}=87,33, \mathrm{SD}=12,02 ; \mathrm{AS}_{\mathrm{M}}=87,97, \mathrm{SD}=12,23 ; \mathrm{t}=1,365 ; \mathrm{p}=\right.$ $0,476)$.

У Табели 3 приказана је дистрибуција студената педагошког и медицинског усмерења по категоријама асертивности. Забележен је мањи проценат студената медицинског усмерења у категоријама ниска и изразито ниска асертивност, као и већи проценат у категоријама висока и изразито висока асертивност. Анализе су показале да је ова разлика у фреквенцијама статистички значајна $\left(\chi^{2}=13,053 ; p=\right.$ $0,011)$.

Табела 3. Дистрибуиија студената педагошког и медицинског усмерења по категоријама асертивности

\begin{tabular}{lcccccc}
\hline & & \multicolumn{5}{c}{ Категорије асертивности } \\
\cline { 2 - 7 } & ИНА* & НА & ПА & ВА & ИВА \\
\hline Педагошко усм. & $\mathrm{f}$ & 23 & 56 & 137 & 67 & 15 \\
& $\%$ & 7,71 & 18,79 & 45,97 & 22,48 & 5,03 \\
\hline Медицинско усм. & $\mathrm{f}$ & 11 & 25 & 98 & 68 & 21 \\
& $\%$ & 4,93 & 11,21 & 43,94 & 30,49 & 9,1 \\
\hline$\sum$ & $\mathrm{f}$ & 34 & 81 & 235 & 135 & 36 \\
& $\%$ & 6,52 & 15,54 & 45,10 & 25,91 & 6,90 \\
\hline
\end{tabular}

ИНА* Изразито ниска асертивност, НА ниска асертивност, ПА просечна асертивност, ВА висока асертивност, ИВА изразито висока асертивност.

\section{Депресивна личност студената}

Да би се испитао степен изражености депресивне личности код студената у укупном узорку и на подузорцима студената педагошких и медицинских усмерења, најпре су добијени резултати на Скали депресивне личности упоређени са нормама које су установљене при конструкцији скале (Табела 4).

Табела 4. Дескриптивни показатељи резултата на Скали депресивне личности у укупном узорку, по усмерењима и у нормативном узорку

\begin{tabular}{lccccc}
\hline & $\mathrm{N}$ & $\mathrm{M}$ & $\mathrm{SD}$ & Мин. & Макс. \\
\hline Педагошко усмерење & 298 & 29,17 & 14,28 & 0,00 & 74,00 \\
Медицинско усмерење & 223 & 28,36 & 14,08 & 0,00 & 74,00 \\
Укупан узорак & 521 & 28,76 & 14,18 & 0,00 & 74,00 \\
Нормативни узорак & 727 & 28,86 & 14,31 & 0,00 & 74,00 \\
\hline
\end{tabular}

Средње вредности укупног узорка и подузорака припадају категорији Одсутне особине депресивне личности (резултат 39 и мање). Добијене просечне вредности у укупном узорку не разликују се у односу на нормативни узорак примењене скале $(\mathrm{t}=-0,071 ; \mathrm{p}=$ 
0,113). Добијене просечне вредности у обе испитиване подгрупе такође се не разликују од просечних вредности нормативног узорка $\left(\mathrm{t}_{\Pi}=-1,062 ; \mathrm{p}=0,129 ; \mathrm{t}_{\mathrm{M}}=-1,083 ; \mathrm{p}=0,141\right)$.

Упркос томе што је средња вредност студената медицинског усмерења мања од средње вредности резултата студената педагошког усмерења, анализе показују да ова разлика није статистички значајна $(\mathrm{t}=-1,351 ; \mathrm{p}=0,159)$. Такође, нема значајне разлике у просечном резултату на ДЛ скали између полова $\left(\mathrm{AS}_{\text {ж }}=28,99, \mathrm{SD}=\right.$ 14,$\left.39 ; \mathrm{AS}_{\mathrm{M}}=28,53, \mathrm{SD}=14,12 ; \mathrm{t}=-1,071 ; \mathrm{p}=0,137\right)$.

У Табели 5 приказана је дистрибуција студената педагошког и медицинског факултета по категоријама депресивне личности. Забележен је мањи проценат студената медицинског усмерења у категоријама Веома наглашене особине депресивне личности и Наглашене особине депресивне личности. Анализе су показале да је ова разлика у фреквенцијама статистички значајна $\left(\chi^{2}=12,925 ; p=0,004\right)$

Табела 5. Дистрибуија студената педагошког и медииинског усмерења по категоријама асертивности

\begin{tabular}{lccccc}
\hline & \multicolumn{4}{c}{ Категорије депресивне личности } \\
\cline { 2 - 6 } & ВНО ДЛ* & НО ДЛ & УИ ДЛ & ОО ДЛ \\
\hline Педагошко усм. & $\mathrm{f}$ & 59 & 65 & 162 & 12 \\
& $\%$ & 19,79 & 21,81 & 54,36 & 4,02 \\
\hline Медицинско усм. & $\mathrm{f}$ & 39 & 46 & 137 & 1 \\
& $\%$ & 17,48 & 20,62 & 61,43 & 0,44 \\
\hline$\Sigma$ & $\mathrm{f}$ & 98 & 111 & 299 & 13 \\
& $\%$ & 18,80 & 21,30 & 57,38 & 2,49 \\
\hline
\end{tabular}

*ВНО ДЛ - Веома наглашене особине депресивне личности, НО

ДЛ - Наглашене особине депресивне личности, УИ ДЛ - Умерено изражене особине депресивне личности, ОО ДЛ - Одсутне особине депресивне личности

\section{Повезаност асертивности и депресивне личности}

Добијене вредности Спирмановог коефицијента корелације показују да је између постигнућа студената на скали асертивности и скали депресивне личности нађена статистички значајна негативна повезаност ниског интензитета $\left(\mathrm{r}_{\mathrm{s}}=-0,287, \mathrm{p}=0,000\right)$.

\section{ДИСКУСИЈА}

Полазећи од уверења да је познавање реалних потенцијала студената на почетку студија неопходан услов планског унапређивања њихових предности и благовременог деловања у правцу корекције недостатака, значаја асертивности и одсуства депресивних тенденција у контексту изградње професионалних компетенција педа- 
гошких и медицинских радника, истраживање је имало за циљ да утврди ниво асертивности и депресивних особина личности студената ових усмерења на почетку студија.

Добијени резултати показују да су средње вредности резултата студената на скали асертивности на доњој граници категорије просечне асертивности и у укупном узорку и у подузорцима. Упркос томе што највећи проценат студената према постигнутим резултатима припада категорији просечне асертивности, проценат студената који се сврстава у категорију изразито ниске и ниске асертивности није занемарив. Осим тога, добијене просечне вредности у укупном узорку и подузорцима су статистички високо значајно мање у односу на нормативни узорак примењене скале асертивности (Biro i sar., 2009). Упоређујући добијене резултате са резултатима расположивих страних истраживања, у којима је нађено да је $48 \%$ студената високо асертивно на почетку студија (Eskin, 2003.; Ibrahim, 2011), можемо видети да је мањи проценат наших студената високо асертиван на почетку студија $(30,49)$.

Добијене резултате можемо схватити у извесном смислу као забрињавајуће будући да је асертивност скоро подједнако важна у обе професије (Lawton \& Stewart, 2005). Важно је да медицински радници свих профила, као и васпитачи и учитељи, развијају вештине асертивности како би својим пацијентима и васпитаницима обезбедили сигурну и ефикасну сарадњу и комуникацију (Unal, 2012). Изражавајући своја осећања, ставове и захтеве искрено, јасно и директно, без анксиозности или застрашивања, они могу оснажити самопоуздање оних са којима раде и обезбедити добру основу за конструктивну комуникацију која води остварењу циљева. Будући да се и од једних и других очекује да управљају и буду лидери, асертивност ће им омогућити и да делују мотивационо како би и они са којима раде могли слободно да изразе своја осећања и ставове. Њихов посао такође подразумева и оснаживање особа са којима раде у правцу унапређења њихове личне аутономије (Watanabe, 2010).

Ипак, добијени резултати могу се посматрати и у контексту резултата иностраних студија које показују да су млади људи мање асертивни на почетку студија и да постају асертивнији током свог академског образовања (Deltsidou, 2008). Ово се може објаснити повезаношћу асертивности и самопоштовања. Високи резултати на асертивности непрестано се доводе у везу са високим резултатима на самопоштовању (Alinčić, 2013). Студенти који су већ завршили једну годину студија, две године или пак више њих свакако имају више самопоуздања од почетника. Објашњење можемо потражити и у самом процесу образовања. Истраживачи су пронашли позитивну повезаност између нивоа асертивности и обука асертивности током њиховог образовања (McCabe \& Timmins, 2005). Ово такође упућује и на 
закључак да би програми асертивног понашања требало да постану компонента свих програма едукације будућих стручњака чији је посао заснован на комуникацији.

Анализе су показале и да се студенти педагошког усмерења не разликују значајно од својих вршњака студената медицинског усмерења. Ипак, добијене су значајне разлике у категоријама ниске, изразито ниске, високе и изразито високе асертивности у корист студената медицинског усмерења. Студенти медицинског усмерења су у значајно већем проценту остварили резултате који их сврставају у категорију високо и изразито високо асертивних личности, које карактерише изразито стабилно самопоуздање, социјалне интеракције засноване на самопоштовању, али и поштовању права других и јасноћа у социјалним интеракцијама. Међу студентима медицинског усмерења нађен је значајно мањи проценат са изразито ниском и ниском асертивношћу, које карактерише изразито ниско самопоуздање, снисходљивост у социјалним интеракцијама, пасивно и субмисивно међуљудско понашање (Tovilović, 2005). Ови резултати могу се тумачити и у светлу чињенице да су медицинска занимања последњих деценија веома тражена на европском тржишту рада и да их углавном уписују млади људи који су завршили гимназије и средње медицинске школе са одличним успехом, оријентисани ка раду у иностранству, што свакако захтева висок степен самопоуздања.

У истраживању нису нађене значајне разлике у нивоу асертивности у односу на пол, што је у складу са резултатима добијеним на нормативном узорку при конструкцији скале коришћене у овом истраживању („Нису установљене разлике у резултатима ни према једној од релевантних социо-демографских варијабли: пол, старост, образовање, место становања") (Tovilović, 2009: 64).

Резултати на скали депресивне личности показали су да највећи проценат студената припада категорији умерено изражених особина депресивне личности, што је, према ауторима теста, нормално постигнуће. Ипак, у укупном узорку је 21,30\% студената који припадају категорији наглашених особина депресивне личности. Овај проценат је забрињавајућ будући да су ово резултати који могу указивати не само на депресивни поремећај личности већ и на друге афективне поремећаје. Уз то, 18,80\% студената остварило је резултате који их сврставају у категорију веома наглашене особине депресивне личности. Овако висок резултат сугерише да особа скоро сигурно задовољава критеријуме за депресивни поремећај личности. Тако висок проценат заслужује посебну пажњу и из разлога што су овакви резултати веома ретки у општој популацији, те би требало мислити и о могућој агравацији („вапај за помоћ”) (Biro i sar., 2009). Свакако, ово захтева даља истраживања. Између студената педагошког факултета и студената медицинских факултета не постоји статистички значајна разлика у изражености особина депресивне личности. 
Није нађена значајна разлика између младића и девојака, што је у складу са налазима наших (Novović, 2004) и страних аутора (Bagby \& Ryder, 1999), упркос томе што је вишеструко потврђено да је склоност ка депресивном реаговању чешћа у женској популацији (Kotov, et al. 2010). Разлог томе можемо потражити у самој суштини депресивне личности која, подсетимо, није дефинисана емоционалним, већ когнитивним аспектима, не емоцијама, већ начином на који људи мисле о себи и другима (Klein, 1999).

Добијене вредности Спирмановог коефицијента корелације показују да је између резултата студената на скали асертивнсти и скали депресивне личности нађена статистички значајна негативна повезаност ниског интензитета. Добијене резултате можемо посматрати и у светлу повезаности асертивности, самопоштовања и депресивности, која је потврђена у многим истраживањима (Shiina, 2005; Calkinset al.2009). Подсетимо, асертивност је најпре проучавана у домену анксиозних и депресивних поремећаја. Показано је да асертивни тренинг смањује ниво анксиозности и побољшава социјалну ефикасност код великог броја анксиозних и депресивних пацијената (Pillemer, 2010). Показало се да већа асертивност доводи до значајног смањења социјалне анксиозности, као и да ниска асертивност може имати предвиђајући значај за развој анксиозних и депресивних поремећаја (Košutić i sar. 2012).

Коначно, верујемо да ово истраживање, упркос ограничењима, отвара важна практична питања. Подсетимо, у раду смо пошли од теоријског одређења асертивности као значајног аспекта социјалних компетенција. Будући да асертивност подразумева сигурност у социјалној интеракцији без агресивности, да је повезана са самопоштовањем и одсуством социјалне анксиозности и депресивних особина личности, мишљења смо да је асертивно понашање једно од најпожељнијих облика понашања у контексту професионалних компетенција педагошких и медицинских радника. Осим тога, сматрамо да је познавање реалних потенцијала студената на почетку студија веома важно како би се плански унапређивале њихове предности и благовремено деловало у правцу корекције недостатака. У том смислу, асертивност студената прве године на доњој граници категорије просечан, значајно нижа средња вредност резултата асертивности у односу на нормативни узорак, проценат студената педагошког и медицинског усмерења са ниском и изразито ниском асертивношћу, као и израженим особинама депресивне личности - указују на неопходност планске активности у правцу развоја асертивности у току студија и примену превентивних програма за заштиту менталног здравља младих у току студија. 


\section{ЗАКЉУЧАК}

Истраживања карактеристика личности студената које су од значаја за изградњу професионалних компетенција на почетку студија веома су ретка у нашој средини. Иако професионалци сматрају да су асертивност и одсуство особина депресивне личности подразумеване одлике младих људи који бирају педагошке и медицинске професије, резултати овог истраживања упозоравају да би овом питању требало посветити већу пажњу. Највећи проценат испитиваних студената је на доњој граници категорије просечне асертивности и у категорији умерено депресивне личности (нормални резултати), док је проценат студената са ниском и изразито ниском асертивношћу и израженим особинама депресивне личности забрињавајућ. У истраживању су поново потврђени налази да између асертивности и депресивне личности постоји статистички значајна негативна повезаност. Све ово указује на то да је студенте који су према резултатима сврстани у категорију ниске и изразито ниске асертивности, као и студенте за израженим особинама депресивне личности, нужно пратити у току студирања с обзиром на поменуту повезаност са анксиозношћу, депресивношћу и самопоштовањем. Анксиозност и друге особине депресивне личности као што су пасивност, песимистичност, несигурност у себе и недостатак асертивности могу бити озбиљна сметња за рад у педагошкој и медицинској професији које захтевају конструктивну комуникацију, стабилност и самопоштовање, али и поштовање права других. Будући да су истраживања недвосмислено потврдила да се асертивност може значајно унапредити вежбањем и да се на тај начин смањује анксиозност у социјалном контексту и побољшавају социјалне вештине, а самим тим смањују и тенденције ка депресивном реаговању, сматрамо да је од изузетне важности за развој професоналних компетенција будућих педагошких и медицинских радника познавање њихових стварних карактеристика на почетку студија и рад на њиховом унапређивању.

\section{ЛИТЕРАТУРА}

APA. (2013). Diagnostic and statistical manual of mental disorders. Fifth Edition (DSM-5. Washington DC, American Psychiatric Association.

Alinčić, M. (2013). Osobine ličnosti i asertivnost kao prediktori samopoštovanja i socijalne anksioznosti. Primjenjena psihologija, 6 (2), 139-157.

Bishop, S. (2006). Develop Your Assertiveness. London: Kogan Page.

Burušić, J. (2007). Samopredstavljanje: taktike i stilovi. Jastrebarsko: Naklada Slap.

Biro, M., Smederevac S., \& Novović, Z. (2009). Procena psiholoških i psihopatolških fenomena. Beograd: CPP.

Calkins, A.W., Otto, M.W., Cohen, L.S., Soares, C.N., Vitonis, A.F., Hearon, B.A., Harlow, B.L. (2009). Psychosocial predictors of the onset of anxiety disorders 
in women: results from a prospective 3-year longitudinal study. $J$ Anxiety Disord. 23(8): 1165-69.

Cambon, K., Dos-Santos Coura, R., Groc, L, Carbon, A., Weissmann, D., Changeux, J.P., Pujol J.F., Granon, S. (2010). Aggressive behavior during social interaction in mice is controlled by the modulation of tyrosine hydroxylase expression in the prefrontal cortex. Neuroscience 171 (3): 840-51.

Cowley, S. (2006). Tajne uspješnog rada u razredu. Zagreb: Školska knjiga.

Dozois, D.A. \& Beck, A. T. (2008). Cognitive schemas, beliefs and assumptions. In: K.S. Dobson \& D.A. Dozois (Eds). Risk factors in depression. San Diego: Academic Press.

Deltsidou, A. (2008). Undergraduate nursing students' level of assertiveness in Greece: Aquestionnaire survey. Nurse Education in Practice, 9(2): 322-330.

Den Hartog, D. N. (2004). Assertiveness. In R. J. Houes, P. J. Hanges, M. Javidan, P. W. Dorfman, \& V. Gupta (Eds.), Culture, Leadreship and Organizations (pp.395-436). Thousand Oaks, CA: Sage.

Djigić, G., Stojiljković, S. (2011). Classroom management styles, classroom climate and school achievement. Procedia-Social and Behavioral Sciences, 29 (2011): 819-828.

Eskin, M. (2003). Self-reported assertiveness in Swedish and Turkish adolescents: A cross-cultural comparison. Scand J Psychol. 44(1): 7-12.

Grkinić, A. (2008). Depresivna ličnost i njeni korelati u Tellegenovom modelu. Diplomski rad. Novi Sad: Filozofski fakultet.

Gladestone, G., \& Parker, G. (2005). Measuring a behavioraly inhibited temperament style: Development and initial validation of new self-report measures. Psychiatry Researrch, 135, 133-143.

Hollander, E., Simeon, D. (2006). Anksiozni poremećaji. Jastrebarsko: Naklada Slap.

Ibrahim, S. A. (2011). Factors affecting assertiveness among student nurses. Nurse Education Today, 31(4), 356-360.

Košutic, Ž., Dukanac V., Bradić, Z., Mitković, M., Mandić-Maravić, V., Pejić, M., Mitić, M., Peulić, A., Raković, I., Lečić-Toševski, D. (2012). Asertivnost kod adolescenata sa anksioznim poremećajima - povezanost sa dimenzijama ličnosti, socijalnom zrelošću i sociodemografskim karakteristikama. Psihijarija danas. 44(1), 47-59.

Klein, D.N. (1999). Depressive personality. Harvard Mental Health Letter 16 (3), 4-3

Klein, D. N., Shankman, S.A. \& Rose, S. (2008). Dysthymic disorder and double depression: prediction of 10-year course trajectories and outcomes. Journal of Psichiatric Research, 42, 408-415.

Lange, A. J., Jakubowski, P.,McGovern, T.V. (1976). Responsible Assertive Behavior: Cognitive/ Behavioral Procedures for Trainers. Michigan: Research Press

Lawton, S., \& Stewart, F., 2005. Assertiveness: making yourself heard in district nursing. British Journal of Community Nursing, 10 (6), 281-283.

Lin, Y., Wu, M., Yang, C., Chen, T., Hsu C. C., Chang Y., Chou, K. (2008), Evaluation of assertive training for psychiatric patients. Journal of Clinical Noursing, 17, 2875-2883.

Locke, K. D., \& Sadler, P. (2007). Self-efficacy, values and complementartity in dyadic interactions: Integrating interpersonal and social-cognitive theory. Personality and Social Psychology Bulletin, 33, 94-109.

Maremmani, I., Akiskal HS., Signoretta, S., Lignori, A., Pervgi, G., Cloninger, R. (2005). The relationship of Kraepelian affective temperaments (as measured by TEMPS-I) to the tridimensional personality questionaire (TPQ). J. Affect. Disord. 85 (1-2): 17-27. 
Makai, M. (2013). Domination \& Submission: The BDSM Relationhip. Handbook. Createspace. pp. 162-171

Mirjanić, L. i Milas, G. (2009). Uloga samopoštovanja u održavanju subjektivne dobrobiti u primjeni strategija suočavanja sa stresom. Društvena istraživanja, 20 (3) 711-727.

Mitrović, R., Mišković, Ž. (2013). Report IPROD 1.2 BU. Beograd: Univerzitet u Beogradu

Novović, Z., Mihić Lj., Tovilović, S. (2009). Procena depresivne ličnosti. U M. Biro, S. Smederevac i Z. Novović (Ur.). Procena psiholoških i psihopatoloških fenomena (str. 63-72). Beograd: Centar za primenjenu psihologiju.

McCabe, C. \& Timmins, F. (2005). Nurses' and midwives' assertive behavior in the workplace. Journal of Advanced Nursing, 51(1), 38-45.

Olsen, L.R., Jensen, D.V., Noerholm, V., Martiny, K., Bech, P. (2003). The internal and external validity of the Major Depression Inventory in measuring severity of depressive states. Psychological medicine 33 (2): 351-6.

Pfeiffer, R. (2010). Relationships: Assertiveness Skills. New Jork: Growth Publishing

Pillemer, K., Suitor, J. J., Pardo, S., Henderson, J., (2010). Mothers' Differentiation and Depressive Symptoms Among Adult Children. Journal of Marriage and Family 72 (2): 333-345.

Pinquart, M., Schiller, F. (2003). Differences Between Caregivers and Noncaregivers in Psychological Health and Physical Health: A Meta-Analysis. Psychology and Aging 18 (2): 250-267

Sarkova, M., Orosova O., Geckova, A.M., Katreniakova, Z., Klein D., Heuvel W., Dijk J.P., (2013). Associations between assertiveness, psychological well-being, and selfesteem in adolescent. Journal of Applied Social Psychology. 43 (1): 147-154,

Shiina, A., Nakazato, M., Mitsumory, M., Koizumi, H., Shimizu, E., Fujisaki, M., \& Iyo, M. (2005). An open trial of outpatient group therapy for bulimic disorders: combination program of cognitive behavioral therapy with assertive trainin and self-esteem anhancement. Psychiatry and Clinical Neurosciences, 59, 690-696.

Schneider, K. (1959). Clinical Psychopathology. New York: Grune and Stratton.

Tavakoli, S., Lumley, M., Hijazi, A., Slavin-Spenny, O., Parris, G. (2009). Effects of Assertiveness Training and Expressive Writing on Acculturative Stress in International Students: A Randomized Trial. Journal of Counseling Psychology (4): 590-596.

Terluter, R., Diehl, S., \& Mueller, B. (2010). The cultural dimension of assertiveness in cross-cultural advertising: The perception and evaluation of assertive advertising appeals. International Journal of Advertising,29(3): 369-399.

Thompson, R. J., \& Berenbaum, H. (2011). Adaptive and Agressive Assertiveness Scales (AAA-S). Psychopathological Behavior Assessment, 33, 323-334.

Tovilović, S., Novović, Z., Biro, M. i Gavrilov-Jerković, V. (2005). Psihometrijske karakteristike Rathusove skale asertivnosti. U. M. Zotović. (Ur.) Psihosocijalni aspekti društvene tranzicije u Srbiji. Novi Sad: Filozofski fakultet.

Tovilović, S. (2005). Asertivni trening: efekti tretmana, održivost promena i udeo terapeuta u terapijskom ishodu. Psihologija, 38, 35-54.

Tovilović, S., Okanović, P. i Krstić, T. (2009). Procena asertivnosti. U M. Biro, S. Smederevac i Z. Novović (Ur.). Procena psiholoških i psihopatoloških fenomena (str. 63-72). Beograd: Centar za primenjenu psihologiju.

Tripathi, N., Nongmaithem, S., Mitkovic, M., Ristic, L, Zdravkovic, J. (2010). Assertiveness and Personality: Cross-Cultural Differences in Indian and Serbian Male Students. Psychol Stud. 55(4): 330-38.

Zdravković, J. (2004). Asertivnost - Veštine vladanja sobom, Niš, Zoograf. 
Zavertnik, J.E., Huff, T.A., \& Munro, C.L. (2010). Innovative approach to teaching communication skills to nursing students. Journal of Nursing Education, 49(2): $65-71$.

Unal, S. (2012). Evaluation the effect of self-awareness and communication techniques on nurses' assertiveness and self-esteem. Contemporary Nurse, 43(1): 90-98.

Vagos, P., \& Pereira, A. (2010). A Proposal for Evaluating Cognition in Assertiveness. Psychological Assessment, 22, 657-665.

Van Dyk, D., Evans, Ch. (2008). Opponent assessment in lizards: examining the effect of aggressive and submissive signals. Behavioral Ecology 19 (4): 895-901.

Vilotijević, M., Vilotijević N., (2014). Vrednovanje kvaliteta rezultata i procesa učenja. Inovacije u nastavi - časopis za savremenu nastavu. 27( 4): 21-30.

Watanabe, A. (2010).The relationship between four components of assertiveness and interpersonal behaviors, interpersonal adjustment in high school students' friendship. Shinrigaku Kenkyu. 81(1): 56-62.

Wolpe, J. (1958). Psychotherapy by Reciprocal Inhibition. California: Stanford University Press.

World Health Organizacion (2011). International statistical classification of diseases and related health problems - 10th revision, edition 2010, Volume 2 (2011).

\title{
ASSERTIVENESS AND DEPRESSIVE PERSONALITY OF STUDENTS OF PEDAGOGICAL AND MEDICAL FACULTIES
}

\author{
Radmila Milovanović ${ }^{1}$, Zorica Marković ${ }^{2}$ \\ ${ }^{1}$ University of Kragujevac, Faculty of Pedagogical Sciences, Kragujevac, Serbia \\ ${ }^{2}$ University of Niš, Faculty of Philosophy, Niš, Serbia
}

\begin{abstract}
Summary
In the context of social competencies, the construct of assertiveness is viewed as a manifestation of social and emotional intelligence which contributes to an adequate adaptation of a person in social interactions, maintenance of socially desirable relationships and emotional well-being of the participants in the social interaction. Studies have found a high negative correlation between assertiveness and social anxiety and suggested that the lack of assertiveness has its affective component and that low assertiveness occupies the position between anxiety and depression. The studies of nonassertiveness and the consequences of non-assertive behaviour have led to the description of non-assertive personalities as withdrawn and fearful, as persons who are incapable of defending their rights, which results in a sense of incompetence and weakening of selfconfidence. The depressive personality has become an object of interest in psychology and psychiatry only recently, in the context of a tendency toward non-assertive and submissive behaviour in the social context. Depressive personalities are described by many authors as quiet, passive, sombre, conscientious, lacking in self-confidence and non-assertive. In the latest classification of disorders, the DSM-V, the depressive personality is characterized by reduced self-respect, high level of self-criticism and a tendency towards self-belittlement. Since assertiveness and the absence of depressive tendencies are important factors in building the professional competencies of pedagogical and medical professionals of all profiles, this research was aimed at examining the assertiveness and the presence of depressive personality traits among students at the
\end{abstract}


beginning of their studies. The total sample consisted of 521 first year students (162 students of the Faculty of Education of the UKG in Jagodina, 136 students of the Faculty of Teacher Education in Užice, 98 students of the High Medical School in Ćuprija, 72 students of the Faculty of Medical Sciences in Kragujevac and 53 students of the Faculty of Medicine in Belgrade). Assertiveness was measured by the Assertiveness Assessment Scale (A Scale) and depressiveness was examined by the Depressive Personality Assessment Scale (DL Scale). Results show that the highest number of students are at the lower limit of the average assertiveness category and have moderately expressed characteristics of depressive personalities. There was no significant difference between students of pedagogical and students of medical orientation in relation to assertiveness $(\mathrm{p}=.498)$ and depressive personality traits $(\mathrm{p}=.159)$. A statistically significant negative correlation of low intensity was found between the student scores on the assertiveness scale and the depressive personality scale $(\mathrm{r}=-.287, \mathrm{p}=.000)$. Given that assertiveness implies security in social interactions without aggressiveness, that it is related to selfrespect and a lack of social anxiety and depressive personality traits, it is our opinion that assertive behaviour represents one of the most desirable forms of behaviour in the context of professional competencies of pedagogical and medical workers. In addition, it is our belief that the knowledge of the real potentials of students at the beginning of their studies is very significant in order to improve their virtues and act in the direction of correcting their shortcomings in a timely manner. In this sense, the assertiveness of first year student which is at the lower limit of the category of average assertiveness, a significantly lower mean value of assertiveness scores in relation to the normative sample, the percentage of students of pedagogical and medical orientation with low and extremely low assertiveness levels, as well as with prominent depressive personality traits, indicate the necessity of planned action directed towards the development of assertiveness and the implementation of preventive programs for the protection of mental health of young people during their studies. 